\title{
RECOLLECTION OF THE EARLY SETTLEMENT OF N. W. IOWA.
} BY N. LEVERING, MEOKLIN, MO.

In order that a mechanic may construct a perfect piece of mechanism, it is highly essential that he should have all the necessary appliances and requisites for the same; without these skill will fall short in accomplishing the object desired. So it is in some degree in my attempting to write a sketch of the early settlement of north-western Iowa. For the want of the proper requisites, such as assistance from some of the pioneer settlers, county records, \&c., I can write but an imperfect sketch, but hope that what I may write fiom memory, and the few dates which $I$ have in my possession, may call out or induce some one of the old settlers in north-western Iowa, to take up the subject and do it the justice that it requires. In this article I will speak mostly of Woodbury County.

In the spring or summer of 1848 , the first settlement was commenced in Woodbury County, by one William ${ }^{V}$ Thompson, from Morgan County, Illinois. It would be proper to state here, that some years prior to Mr. Thompson's arrival there were a number of Canadian French in scattering settlements along the Missouri River, in Woodbury and adjoining counties, for the purpose of trading and trafficing with the aborigines with whom they had become allied by the ties of affinity and consanguinity. This class of persons could not properly be called actual settlers.

Mr. Thompson (or old Bill, as he was familliarly called) was a tall athletic and muscular man, eccentric in his habits, but possessing a kind heart and an enterprising spirit. He had no family with him, having buried his wife in Illinois, a short time previous to his emigrating to north-western Iowa. She left him two sons, whom he put in charge of some of his relatives, having thus arranged his family and domestic nutters, and being in a manner unchained from the world, he shoved out for the north-west, and brought up at Floyd's Bluff, in Woodbury County, Iowa, about two miles below where Sioux City now stands, where he bought or made a 
claim, which included Floyd's Bluff. The Indian title to these lands had been extinguished the previous year (1847), and all north-western Iowa was thrown open for settlement. $\mathrm{Mr}^{\mathrm{V}}$ Thompson, anticipating a heavy immigration, and believing that the rich and fertile prairies of the north-west, would soon be occupied by an industrious and enterprising people, he thonght to lay the foundation of a nucleus, around which would cluster the business and eommercial interests of the country. Accordingly he laid off a town at Floyd's Bluff, naming it Thompson town, in honor of himself, which like most of western towns was destined to be the point. But unfortunately for the locality, it had no permanent landing for boats, and the city so abrupt and bluffy, that it was said that the lots hung up by the corners, so that both sides could be cultivated, consequently the enterprise proved an entire failure. To give his town an aspect of improvement, more than the stakes which designated the lots, he erected a cabin, which was soon after occupied by one Mr. Townsley and family. Mrs. Townsley was, I think, the first white woman in Woodbury County.

Mr. Thompson soon after erected a mill for grinding corn, propelled by horse power, which I believe was the first mill built in the county. Soon after his location at this point, he was followed by his brother Charles, who also secured a claim adjoining that of his brother. Numerous bands of Indians were roaming through the country and watching with no little interest the progress of their pale faced brethren, and their increasing numbers. Game such as buffalo, elk, deer, turkeys, beaver, \&c., abounded. Wild fruits of the choicest and most luxuriant character common to the western country, such as grapes plumbs, raspberries, \&c., were found here in great quantities, and supplied our pioneer settler's tables with many lnxuries.

In the spring of 1849 , Theophile Bruigher, a Canadian Frenchman, came down from the headwaters of the Missouri River, where he had been employed in the services of the American Fur Company, and settled near the mouth of the 
Big Sioux River, on the Iowa side, about two and a half miles above where Sioux City now stands. He had two squaw wives, both of whom were daughters of the celebrated Sioux chief, War Eagle.

In May, 1857, Mr. B. buried one of his wives, and I think the following year he buried the other. They left him thirteen children, all of whom drew their half-breed script from the government for three hundred and twenty acres of land each, making in all four thousand one hundred and sixty acres a liberal premium for half-breeds. Congress undoubtedly made a very grave mistake when it passed the act granting to each half-breed Indian three hundred and twenty acres of land, issuing script for the same, which half-breed script is allowed to be laid on any government lands, whether in market or not; thus in a manner offering a premium on half-breeds. I will not stop here to discuss the evils flowing from and attendant upon such a law, as the reader will perceive at a glance its demoralizing and degrading influence. Mr. B. still resides there, the proprietor of a very large and excellent farm.

If I am correctly informed, sometime in the fall of 1849 , Robert ${ }^{*}$ Perry, a man of some literary attainment, but of peculiar and eccentric mind, emigrated from the District of Columbia, and settled in what is now Sioux City proper, where he erected a cabin on the bank of a small stream that now bears his name. It is said that Mr. Perry at one time imbibed a little too freely of the "overjoyful," and while laboring under its exhilarating influence, was precipitated into the stream, which has since that time borne his name. In 1851, he removed, I believe, back to some of the eastern states.

What is now known as Sioux City East Addition, was owned and occupied by Mr. Bruigher, as a cornfield (it had formaly been occupied by the Indians for the same purpose). In 1852 , he sold the same to a Canadian Frenchman by the name of Jas.'Lionais, for one thousand dollars. This year quite a number of Frenchmen at Fort Vermillion, and vicin- 
ity, in Dakota Territory, got involved in difficulty with the Indians at that point, and consulting their own safety, descended the Missouri River to where Sioux ${ }^{V}$ City now stands, where they stopped for a few months, leaving again for various points. In 1853 , the county was organized for judicial and revenue purposes, and the county seat located by an act of the legislature at Thompson town.

In the spring of 1854 , Dr. John K. Cook, an Englishman by birth, had a contract from the government to sectionize most of the counties in north-western Iowa, came up from Conncil Bluffs, where he then resided, for the purpose of prosecuting his work. The Dr. was not long in discerning the natural beauty and advantages in this point for a town. Accordingly he and some of his party staked off claims preparatory to laying off a town. Amongst those who made claims, were Hiram Nelson, S. W.'Chamberlin and Dr. F. 'Wixon. The following winter of 1854-5, a town was laid out and called Sioux city, after the Sioux Indians, who had been the former occupants of the country.

\section{OLD SOLDIERS.}

\section{BY F. SNYDER.}

"He who preaches war," said the Hon. Horace Mann, " is a fit chaplain for the devil."

Whether the distinguished educator was correct, judge ye. One thing is certain, that ever since Satan "raised impious war in heaven," mankind have been engaged in sanguinary conflict. But of all wars of the past, we Americans look back with patriotic pride on the heroic deeds of our forefathers, especially those who fought the battles of the revolution and war of 1812. Of the latter war, there resides in the town of Le Claire, Scott County, the following old soldiers: James Haskell, seventy-five years of age, was a member of the United States Light Artillery, under Gen. Wilkinson. Mr. Haskell had a son, George, who was killed in the war of 1862 , in Missouri. Henry 'Stone, seventy-six years of age, one of the "Green Mountain boys," fought at the battle of Plattsburgh. He is the father of the Dr. Stone whose name was 
Copyright of Annals of Iowa is the property of State of Iowa, by \& through the State Historical Society of Iowa and its content may not be copied or emailed to multiple sites or posted to a listserv without the copyright holder's express written permission. However, users may print, download, or email articles for individual use. 